\title{
Individuals Demographic Differences and Financial Satisfaction: Evidence from Pakistan
}

\author{
Muhammad Nauman Sadiq ${ }^{1}$, Raja Ased Azad Khan ${ }^{2}$ and Muhammad Kamran Bashir ${ }^{3}$ \\ ${ }^{1}$ Government Post Graduate (Boys) College Bagh, AJ\&K, Pakistan \\ ${ }^{2}$ Islamic International University, Islamabad, Pakistan \\ ${ }^{3} \mathrm{MS}$ management Science, Hamdard University, Islamabad, Pakistan
}

*Corresponding author: Muhammad Nauman Sadiq, Lecturer, Government Post Graduate (Boys) College Bagh, AJ\&K, Pakistan, Tel: + 923335766716; E-mail: nauman_sns22@yahoo.com

Received date: Jun 12, 2018; Accepted date: Aug 24, 2018; Published date: Aug 31, 2018

Copyright: (c) 2018 Sadiq MN et al. This is an open-access article distributed under the terms of the Creative Commons Attribution License, which permits unrestricted use, distribution, and reproduction in any medium, provided the original author and source are credited.

\begin{abstract}
The purpose of this study was to examine the effect of demographic characteristics on financial satisfaction of individual investors in Pakistan. Base on a sample of 118 individual investors, Chi square test was conducted to investigate that which demographic characteristics are associated with financial satisfaction. Study revealed investors age and family size has significant effect on financial satisfaction. While investor gender, marital status, qualification, occupation, and income level has no influence on financial satisfaction. Present study is significant for the policy makers to understand the individual's financial satisfaction levels according to their gender, age, academic qualification, income level, marital status, occupation, financial knowledge, and family size.
\end{abstract}

Keywords: Demographic characteristics; Financial satisfaction; Individuals investors of Pakistan

\section{Introduction}

Individuals overall life satisfaction relates to series of life aspects. According to aspects includes "emphasizing the positive things in life, working in an area that one enjoys, taking care of one's finances, having relationships with happy people, overcoming negative events and learning from them, and being involved in pleasurable activities that enhance one's positive view of life and offer greater satisfaction". Among these attributes, individual's overall life satisfaction is mainly connected with their financial satisfaction.

"Positive financial behaviors contribute to financial satisfaction and financial satisfaction in turn contributes to life satisfaction".

Several studies divulge that individual's financial satisfaction is an important factor for overall life satisfaction [1,2]. Increasing healthcare expenses, children educational cost, and family needs required an individual to plan for long term to meet future financial satisfaction and protection [3].

According to the ministry of Finance (Pakistan, 2016-2017) "Public Expenditure on Education as percentage to GDP is estimated at 2.3 percentage in FY 2016 as compared to 2.2 percentage of GDP in FY2015. Along this the disease pattern is heavily dominated by malnutrition and poor dietary practices". These results shown that in Pakistan educational and healthcare expenses are increasing. These increasing expenses triggered the dissatisfaction of individuals with financial position. People who are dissatisfied with their conditions are more likely to have low self-esteem, anxiety, fear, and frustration.

Study conducted in Pakistan disclosed that some behavior biases of individuals have impact on their financial satisfaction. This study exposed behavioral biases like overconfidence and categorization tendency has significant positive impact on investor's financial satisfaction levels. Others behavioral biases like Reliance on experts, Self-control bias, budgeting tendency, adaptive tendency has no significant impact on investor's levels of financial satisfaction [4]. Present study attempts to understand the money aspect of life satisfaction for the Pakistani individuals by finding the answer of the question that "Do demographic characteristics have an effect on financial satisfaction"? This increasing financial satisfaction level can cause intention for investment in individuals.

Present study is important for the policy makers to understand the individual's financial satisfaction level according to their gender, age, academic qualification, income level, marital status, occupation, financial knowledge, and family size. According to Sahi, [5] "policy makers would benefit from such empirical work as the study identifies changes that need to be made on a national level that would enable increase in financial satisfaction levels of the people".

\section{Literature Review}

\section{Gender and financial satisfaction}

Generally, it is perceived that men are more financially satisfied than women. This perception is supported by various studies and explored the similar results. These results are also supported by Bonke [6] and found a positive Relationship is exists between men and financial satisfaction, and female investors have less financial satisfaction [7].

Most of studies shown that investors gender has no significant influence on their financial satisfaction, Investors they are either male or female have the same level of financial satisfaction $[5,8]$.

Based on the above literature investors gender is expected to have effect on financial satisfaction.

Hypothesis (1): Investors gender has significant effect on financial satisfaction. 


\section{Age and financial satisfaction}

Age is also considered as a factor affecting the individual's satisfaction with financial matters. According to the study conducted by Sahi [5] in India "age has a positive and significant association with financial satisfaction". This result supports the various previous studies [7,9-12]. Another previous study also supports these results and disclosed that "older people, despite their lower levels of income, are more satisfied financially than younger people. High satisfaction among the elderly also appears to occur even at very low levels of income" [13]. Silda [3] in his study disclosed that among all demographic factors, age was the factor which shown significant impact on financial satisfaction. Similar study conducted in America disclosed that older Americans are very satisfied with their financial position [14]. Statistics regarding Norway also shown Norwegians older individuals are more financially satisfied [15]. Along these results some studies shown investor age has no significant impact on financial satisfaction [8].

Based on the above literature investors age is expected to have effect on financial satisfaction.

Hypothesis (2): Investors Age has significant effect on financial satisfaction.

\section{Income and financial satisfaction}

Most of prior studies intensively focused on the relationship between income and financial satisfaction $[14,16]$. These studies shown individuals income level has significant effect on subjective well-being $[10,17,18]$. Another study also disclosed similar results and concluded that "income was the ultimate source of financial satisfaction and higher income levels contributed to higher satisfaction with financial status. Money is an significant resource which is important for the individual to meet various social and material needs and hence is directly related to individual's financial satisfaction" [19]. Sahi, [5] in her study in India also supports these results and concluded that along other demographic factors like occupation, age, marital status individual's income level has significant impact on their financial satisfaction. These results were also disclosed by Joo and Grable [8] that investor age has significant impact on financial satisfaction.

Based on the above literature Income was expected to have significant impact the financial satisfaction of individuals.

Hypothesis (3): Increasing income level caused an increase in financial satisfaction.

\section{Marital status and financial satisfaction}

Sahi [5] in her study revealed that "Married people are more financially satisfied than single respondents". Numerous previous studies also disclosed that significant positive relationship is exist between marriage and financial satisfaction [20,21]. Joo and Grable [8] in their study disclosed that along other demographic factors like gender, age, and ethnicity marital status also has no significant impact on financial satisfaction.

Based on the above literature investors marital status is expected to have effect on financial satisfaction.

Hypothesis (4): Investors marital status has significant effect on financial satisfaction.

\section{Academic qualification and financial satisfaction}

Generally, it is perceived that academic qualification caused a financial satisfaction in individuals. Study disclosed "it is very possible that those with higher education earn more and hence are more likely to be financially satisfied. Further this study disclosed that it is also possible that a person with high education being dissatisfied with his financial position simply due to the fact that he is relatively less well off financially, rather than being actually deprived in any material way" [22]. Another study also shown similar results and concluded that academic qualification of individuals has significant impact on financial satisfaction [20]. Another study divulged that education has no direct effect on financial satisfaction, however, academic education has indirect effect on financial satisfaction [8].

Along these results some studies find academic qualification has no significant impact on individual level of financial satisfaction [5].

Based on the above literature academic qualification was expected to have significant impact on the financial satisfaction of individuals.

Hypothesis (5): Academic qualification caused an increase in financial satisfaction.

\section{Occupation and financial knowledge}

Investors occupational status is also considered as a factor which influence the investors level of financial satisfaction. However, very little studies have been conducted on this topic. Study conducted by Vera-Toscano et al. [19] explored that "people who are unemployed and retired, are having low levels of financial satisfaction, while for the students and the housewives, no significant relationship with financial satisfaction has been observed".

Sahi [5] in her study disclosed that "the people who are employed with government and semi-government organizations are found to have higher levels of financial satisfaction than other occupational profiles. This is because of a sense of security that is attached to the government jobs as compared to jobs in the private sector".

Based on the above literature occupational status was expected to have significant impact on the financial satisfaction of individuals.

Hypothesis (6): Occupational status has significant effect on financial satisfaction.

\section{Family size and financial satisfaction}

Numerous studies revealed that individual's family size have a significant impact on financial satisfaction. In his study disclosed that "joint family provides to the individual emotional, social and economic support and hence men who live in joint families have more satisfaction with their income levels, than those living in nuclear families".

Beside these results numerous studies shown no significant relationship is exist between family size and financial satisfaction. Joo and Grable [8] in their study disclosed that "no direct relationship between number of dependents in the household, but their study found a negative indirect effect of the number of dependents on financial satisfaction also support these results.

Based on the above literature family size was expected to have significant effect on the Financial satisfaction of individuals. 
Page 3 of 7

Hypothesis (7): Family size has significant effect on financial satisfaction (Figure 1).

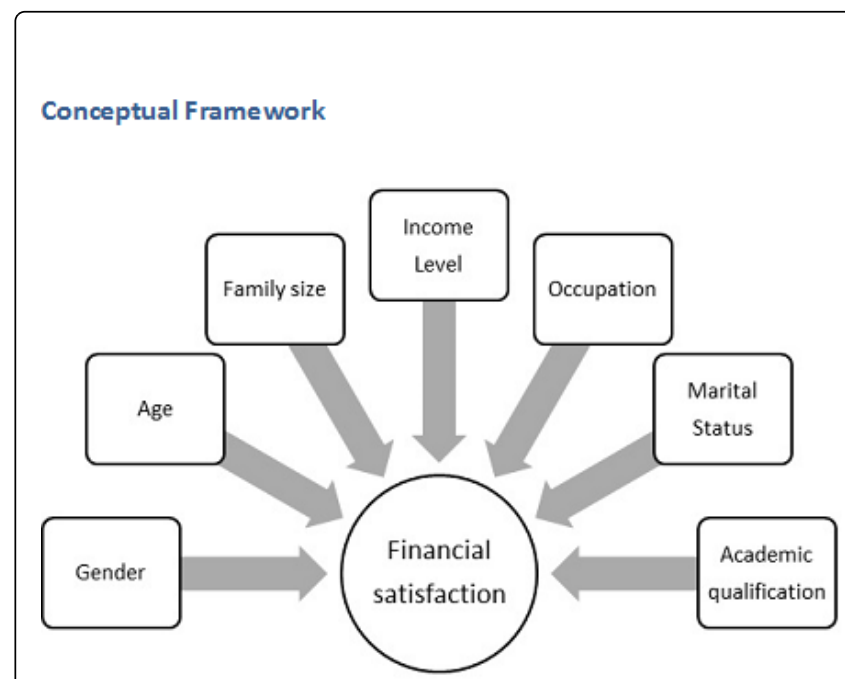

Figure 1: Conceptual framework of financial satisfaction.

\section{Methodology}

\section{Population and sample}

The population for the present study consists of investors having some financial knowledge or investment experience in Long term saving products such as insurance, saving accounts etc. Present study attempts to cover all types of individuals with different professional background. Age group, income level, gender, marital status, academic qualification, financial knowledge, and family size. Conveyance sampling method was used to interact the individuals Present study has interacted about 150 investors. Out of which 120 returns the questionnaires. After scrutinizing of questionnaires, we found 118 questionnaires which were completed and used by the study.

\section{Variable, instrument and measures}

Financial satisfaction: Financial satisfaction or financial well-being was rated on a 10-point self-assessment scale developed by Prawitz et al. [23]. According to the Prawitz et al. [23] this 8-item IFDFW Scale included "four items that represented a sense of one's present state of financial wellbeing and four items that characterized one's reaction to his or her present state of financial well-being" [24].

In order to sorts the individuals according to their Financial Satisfaction, Study divide the it into three groups. Individuals having aggregate score between 1.0-4.0 represents "high financial distress/low financial well-being". Individuals having score between 4.1-6.9 represents "average financial distress/average financial well-being scored between 7-10 represents "low financial distress/high financial well-being".

Demographic factors: Present study used seven demographic characteristics of individuals. These characteristics included individuals Gender, Profession, Marital status, Age, Family size, Academic-qualification, Income level, and financial knowledge.

Each characteristic is divided into subgroup to sort the individuals such as gender is sub-categories into male and female, Occupation is divided into service, profession, students, and business. Marital status is divided into single, married, widow, and divorced. Age is divided into below 30 years, $30-40$ years, $40-50$ years, $50-60$ years, 60 years or above. Family size is divided into 2 members, 3-5 members, 6-8 members, 9 or more members. Qualification is divided into nongraduate, graduate, post graduate, professional education, or others. Income level is divided into Below Rs. 200,000, Rs. 200,000 -400,000, Rs. $400,000-600,000$, Rs. $600,000-800,000$, Rs. 800,000 or above.

\section{Data analysis}

Present study used the chi-square test to find the difference between individual's financial satisfaction level according to their demographic characteristics. Statistical package SPSS was used to conduct this test (Tables 1 and 2).

\begin{tabular}{|c|c|c|c|c|c|}
\hline & & \multicolumn{3}{|c|}{ Financial satisfaction } & \multirow{3}{*}{$\begin{array}{l}\text { Total } \\
93\end{array}$} \\
\hline & & Low & Average & High & \\
\hline \multirow[b]{2}{*}{ Gender } & Male & 3 & 73 & 17 & \\
\hline & Female & 0 & 21 & 4 & 25 \\
\hline Total & & 3 & 94 & 21 & 118 \\
\hline
\end{tabular}

Table 1: Degree of relationship between gender and financial satisfaction.

\begin{tabular}{|l|l|l|l|}
\hline & Value & df & Asymp. Sig. (2-sided) \\
\hline Pearson Chi-Square & $.939^{\mathrm{a}}$ & 2 & 0.625 \\
\hline a3 cells (50.0\%) have expected count less than 5. The minimum expected count is .64. \\
\hline
\end{tabular}

Table 2: Chi-Square test. 
Citation: Sadiq MN, Khan RAA, Bashir MK (2018) Individuals Demographic Differences and Financial Satisfaction: Evidence from Pakistan. Bus

Page 4 of 7

Calculated value of chi-square is .939 , where table value at 0.05 significance level and 2 degree of freedom is 5.991, where calculated value is less than the critical value, null hypothesis is accepted and concluded that there is no relationship between gender and financial satisfaction (Tables 3 and 4).

\begin{tabular}{|c|c|c|c|c|c|}
\hline & & Finan & tion & & Total \\
\hline & & Low & Average & High & \\
\hline & Less than 30 & 3 & 62 & 19 & 84 \\
\hline & $30-40$ & 0 & 20 & 0 & 20 \\
\hline & $40-50$ & 0 & 12 & 0 & 12 \\
\hline & $50-60$ & 0 & 0 & 2 & 2 \\
\hline Total & & 3 & 94 & 21 & 118 \\
\hline
\end{tabular}

Table 3: Degree of relationship between age and financial satisfaction.

\begin{tabular}{|l|l|l|l|}
\hline & Value & df & Asymp. Sig. (2-sided) \\
\hline Pearson Chi-Square & $19.217^{\mathrm{a}}$ & 6 & 0.004 \\
\hline a8 cells (66.7\%) have expected count less than 5. The minimum expected count is .05. \\
\hline
\end{tabular}

Table 4: Chi Square test.

Calculated value of chi-square is 19.217 , where table value at 0.05 significance level and 6 degree of freedom is 12.592, where calculated value is greater than the critical value, null hypothesis is rejected and concluded that there is relationship between age and financial satisfaction. Table 3 shows individuals having age less than 30 are more financially satisfied, while individuals having life between 30 to 50 are average financially satisfied. While individuals having age above 50 are also more satisfied (Tables 5 and 6).

\begin{tabular}{|c|c|c|c|c|c|}
\hline & & \multicolumn{3}{|c|}{ Financial satisfaction } & \multirow[t]{2}{*}{ Tota } \\
\hline & & Low & Average & High & \\
\hline \multirow{5}{*}{ Qualification } & Non Graduate & 2 & 30 & 9 & 41 \\
\hline & Graduate & 1 & 10 & 4 & 15 \\
\hline & Post graduate & 0 & 46 & 8 & 54 \\
\hline & Professional education & 0 & 6 & 0 & 6 \\
\hline & Others & 0 & 2 & 0 & 2 \\
\hline Total & & 3 & 94 & 21 & 118 \\
\hline
\end{tabular}

Table 5: Degree of relationship between qualification and financial satisfaction.

\begin{tabular}{|l|l|l|l|}
\hline & Value & df & Asymp. Sig. (2-sided) \\
\hline Pearson Chi-Square & $7.371^{\mathrm{a}}$ & 8 & 0.497 \\
\hline a10 cells $(66.7 \%)$ have expected count less than 5. The minimum expected count is .05. & \\
\hline
\end{tabular}

Table 6: Chi-Square test.

Calculated value of chi-square is 7.371 , where table value at 0.05 significance level and 8 degree of freedom is 15.507 , where calculated value is less than the critical value, null hypothesis is accepted and concluded that there is no relationship between qualification and financial satisfaction (Tables 7 and 8). 
Citation: Sadiq MN, Khan RAA, Bashir MK (2018) Individuals Demographic Differences and Financial Satisfaction: Evidence from Pakistan. Bus

\begin{tabular}{|c|c|c|c|c|c|}
\hline & & \multicolumn{3}{|c|}{ Financial satisfaction } & \multirow{3}{*}{\begin{tabular}{|l} 
Total \\
41
\end{tabular}} \\
\hline & & Low & Average & High & \\
\hline \multirow[t]{5}{*}{ Qualification } & Non Graduate & 2 & 30 & 9 & \\
\hline & Graduate & 1 & 10 & 4 & 15 \\
\hline & Post graduate & 0 & 46 & 8 & 54 \\
\hline & Professional education & 0 & 6 & 0 & 6 \\
\hline & Others & 0 & 2 & 0 & 2 \\
\hline Total & & 3 & 94 & 21 & 118 \\
\hline
\end{tabular}

Table 7: Degree of relationship between income level and financial satisfaction.

\begin{tabular}{|l|l|l|l|}
\hline & Value & df & Asymp. Sig. (2-sided) \\
\hline Pearson Chi-Square & 8.737 & 6 & 0.189 \\
\hline
\end{tabular}

Table 8: Chi-Square test.

Calculated value of chi-square is 8.737 , where table value at 0.05 significance level and 6 degree of freedom is 12.592, where calculated value is less than the critical value, null hypothesis is accepted and concluded that there is no relationship between income and financial satisfaction (Tables 9 and 10).

\begin{tabular}{|c|c|c|c|c|c|}
\hline & & \multicolumn{3}{|c|}{ Financial satisfaction } & \multirow{3}{*}{$\begin{array}{l}\text { Total } \\
77\end{array}$} \\
\hline & & Low & Average & High & \\
\hline \multirow{3}{*}{ Marital status } & Single & 3 & 61 & 13 & \\
\hline & Married & 0 & 32 & 8 & 40 \\
\hline & Divorced & 0 & 1 & 0 & 1 \\
\hline Total & & 3 & 94 & 21 & 118 \\
\hline
\end{tabular}

Table 9: Degree of relationship between marital status and financial satisfaction.

\begin{tabular}{|l|l|l|l|}
\hline & Value & df & Asymp. Sig. (2-sided) \\
\hline Pearson Chi-Square & $1.975^{\mathrm{a}}$ & 4 & 0.74 \\
\hline
\end{tabular}

Table 10: Chi-Square test.

Calculated value of chi-square is 1.975 , where table value at 0.05 significance level and 4 degree of freedom is 9.488 , where calculated value is less than the critical value, null hypothesis is accepted and concluded that there is no relationship between marital status and financial satisfaction (Tables 11 and 12). 
Citation: Sadiq MN, Khan RAA, Bashir MK (2018) Individuals Demographic Differences and Financial Satisfaction: Evidence from Pakistan. Bus

Page 6 of 7

\begin{tabular}{|c|c|c|c|c|c|}
\hline \multirow[t]{5}{*}{ Occupation } & Government/semi-government & 0 & 18 & 9 & 27 \\
\hline & Professional & 0 & 25 & 0 & 25 \\
\hline & Private service & 3 & 46 & 12 & 61 \\
\hline & Business & 0 & 4 & 0 & 4 \\
\hline & Others & 0 & 1 & 0 & 1 \\
\hline Total & & 3 & 94 & 21 & 118 \\
\hline
\end{tabular}

Table 11: Degree of relationship between occupation and financial satisfaction.

\begin{tabular}{|l|l|l|l|}
\hline & Value & df & Asymp. Sig. (2-sided) \\
\hline Pearson Chi-Square & $14.194^{\mathrm{a}}$ & 8 & 0.077 \\
\hline a11 cells $(73.3 \%)$ have expected count less than 5. The minimum expected count is .03. \\
\hline
\end{tabular}

Table 12: Chi-Square test.

Calculated value of chi-square is 14.19 , where table value at 0.05 significance level and 8 degree of freedom is 15.507 , where calculated value is less than the critical value, null hypothesis is accepted and concluded that there is no relationship between occupation and financial satisfaction (Tables 13 and 14).

\begin{tabular}{|c|c|c|c|c|c|}
\hline & & \multicolumn{3}{|c|}{ Financial satisfaction } & \multirow[t]{2}{*}{ Total } \\
\hline & & Low & Average & High & \\
\hline \multirow[t]{4}{*}{ Family Size } & 2 members & 1 & 12 & 0 & 13 \\
\hline & 3-5 members & 2 & 49 & 7 & 58 \\
\hline & 6-8 members & 0 & 27 & 8 & 35 \\
\hline & 9 or above members & 0 & 6 & 6 & 12 \\
\hline Total & & 3 & 94 & 21 & 118 \\
\hline
\end{tabular}

Table 13: Degree of relationship between family size and financial satisfaction.

\begin{tabular}{|l|l|l|l|}
\hline & Value & df & Asymp. Sig. (2-sided) \\
\hline Pearson Chi-Square & $15.401^{\text {a }}$ & 6 & 0.017 \\
\hline a6 cells (50.0\%) have expected count less than 5. The minimum expected count is .31. \\
\hline
\end{tabular}

Table 14: Chi-Square test.

Calculated value of chi-square is 15.401 , where table value at 0.05 significance level and 6 degree of freedom is 12.592, where calculated value is greater than the critical value, null hypothesis is rejected and concluded that there is relationship between family size and financial satisfaction.

\section{Conclusion}

The purpose of this study was to analyse the effect of demographic characteristics on financial satisfaction of individual investors in Pakistan. Study shown investors age and family size has significant effect on financial satisfaction. These finding revealed that increasing family size caused an increase in financial satisfaction, which shown increasing population does not influence the financial satisfaction at individual level. While investor gender, marital status, qualification, occupation, and income level do not influence financial satisfaction. Present study is important for the policy makers to understand the individual's financial satisfaction levels according to their gender, age, academic qualification, income level, marital status, occupation, financial knowledge, and family size. 
Citation: Sadiq MN, Khan RAA, Bashir MK (2018) Individuals Demographic Differences and Financial Satisfaction: Evidence from Pakistan. Bus

Page 7 of 7

\section{Limitations}

Present study is only designed to understand the effect of demographic characteristic on individual's financial satisfaction level. Data for the present study was collected from Rawalpindi and Islamabad. Further research needs to be directed with more data and across various demographic profiles, from several cities, to increase the generalisability of the findings in the Pakistani context. Further study should be conducted to understand why people in Pakistan feel more financial satisfaction with an increase in family size. Beside this further study should also be directed to understand why financial satisfaction goes on diminished in Pakistan with an increase in Age.

\section{References}

1. Xiao JJ, Tang C, Shim S (2009) Acting for happiness: financial behaviour and life satisfaction of college students. Soc Indic Res 92: 53-68.

2. Mammen S, Helmick SA, Metzen EJ (1983) Financial well-being and life satisfaction. In: Dunsing $M$ editor. Proceedings of the Midwest Symposium on Perceived Economic Well-Being. Urbana, IL: Agricultural Experiment Station, University of Illinois, pp: 8-13.

3. Silda C (2016) Understanding Factors Affecting Financial Satisfaction: The Influence of Financial Behavior, Financial Knowledge and Demographics. Imp J Interdiscipl Res.

4. Sadiq MN, Khan RAA, Bashir MK, Ejaz M (2017) Impact of Psychological Biases of Investors in Financial Satisfaction. Am Based Res J.

5. Sahi SK (2013) Demographic and socio-economic determinants of financial satisfaction: A study of SEC-A segment of individual investors in India. Int J Soc Econ 40: 127-150.

6. Bonke J (2008) Income distribution and financial satisfaction between spouses in Europe. J Socio-Econ 37: 2291-2303.

7. Loibl C, Hira TK (2005) Impact of self-directed financial learning on financial and career satisfaction of white-collar employees. Financ Couns Plann 16: 11-21.

8. Joo S, Grable JE (2004) An exploratory framework of the determinants of financial satisfaction. J Fam Econ Issues 25: 25-50.

9. Horley J, Lavery JJ (1995) Subjective well-being and age. Soc Indic Res 34: 275-282.

10. La Barbera PA, Gürhan Z (1997) The role of materialism, religiosity, and demographics in subjective well-being. Psychol Marketing 14: 71-97.
11. Xiao JJ, Sorhaindo B, Garman ET (2006) Financial behaviours of consumers in credit counselling. Int J Consum Stud 30: 108-121.

12. Hansen T, Slagsvold B, Moum T (2008) Financial satisfaction in old age: a satisfaction paradox or a result of accumulated wealth? Soc Indic Res 89: 323-347.

13. Olson GI, Schober BI (1993) The satisfied poor. Soc Indic Res 28: 173-193.

14. George LK (1994) Financial security in later life: The subjective side. J Am Soc CLU \& ChFC.

15. Statistics Norway (2006) Economy and living for different groups [Personal economy and housing conditions].

16. Diener E, Sandvik E, Seidlitz L, Diener M (1993) The relationship between income and subjective well-being: Relative or absolute? Soc Indic Res 28: 195-223.

17. Headey B, Veenhoven R, Wearing A (1991) Top-down versus bottom-up theories of subjective well-being. Soc Indic Res 24: 81-100.

18. George LK (1992) Economic status and subjective well-being: A review of literature and an agenda for future research. In Cutler NE, Gregg DW, Lawton MP (Eds.), Aging, money, and life satisfaction: Aspects of financial gerontology. New York: Springer, pp. 69-99.

19. Vera-Toscano E, Ateca-Amestoy V, Serrano-Del-Rosal R (2006) Building financial satisfaction. Soc Indic Res 77: 211-243.

20. Hira TK, Mugenda O (1998) Predictors of financial satisfaction: differences between retirees and non-retirees. Financ Couns Plann 9: 75-83.

21. Zurlo KA (2009) Personal attributes and the financial well-being of older adults: the effects of control beliefs. Population Aging Research CenterPARC working papers.

22. Pu C, Huang N, Tang GJ, Chou YJ (2011) When does poor subjective financial position hurt the elderly? Testing the interaction with educational attainment using a national representative longitudinal survey. BMC Public Hlth 11: 166.

23. Prawitz AD, Garman ET, Sorhaindo B, O’Neill B, Kim J et al. (2006) In Charge financial distress/financial well-being scale: development, administration, and score interpretation. Financ Couns Plann 17: 34-50.

24. Diener E, Biswas-Diener R (2005) Psychological empowerment and subjective well-being. In Narayan D (Ed.), Measuring Empowerment: Cross-disciplinary Perspectives, The World Bank, Washington, pp: $125-140$ 